\title{
Chromium (VI) reduction in activated sludge bacteria exposed to high chromium loading: Brits culture (South Africa)
}

\author{
Pulane E. Molokwane, Kakonge C. Meli, Evans M. Nkhalambayausi-Chirwa* \\ Water Utilisation Division, Department of Chemical Engineering, University of Pretoria, Pretoria 0002, South Africa
}

\section{A R T I C L E I N F O}

\section{Article history:}

Received 23 April 2008

Received in revised form

28 July 2008

Accepted 30 July 2008

Published online

Keywords:

Indigenous cultures

$\mathrm{Cr}$ (VI) reduction

Culture characterisation

Biocatalysis

Bacillus sp.

Microbacterium sp.

\begin{abstract}
A B S T R A C T
A mixed-culture of bacteria collected from a wastewater treatment plant in Brits, NorthWest Province (South Africa) biocatalytically reduced $\mathrm{Cr}(\mathrm{VI})$ at much higher concentrations than previously observed in cultures isolated in North America. $\mathrm{Cr}(\mathrm{VI})$ reduction rate up to 8 times higher than the rate in previous cultures was achieved by the Brits culture under aerobic conditions. Near complete $\mathrm{Cr}(\mathrm{VI})$ reduction was observed in batches under initial concentrations up to $200 \mathrm{mg} \mathrm{Cr}(\mathrm{VI}) / \mathrm{L}$ after incubation for $65 \mathrm{~h}$ in aerobic cultures. Under anaerobic conditions up to $150 \mathrm{mg} \mathrm{Cr}(\mathrm{VI}) / \mathrm{L}$ was completely removed after incubating for 130-155 h. In the previous cultures, complete removal was only achieved in cultures at an initial $\mathrm{Cr}(\mathrm{VI})$ concentration lower than $30 \mathrm{mg} / \mathrm{L}$ after incubation for $96-110 \mathrm{~h}$. Consortium cultures were characterised using 16S rRNA partial sequence analysis. Results showed that the Gram-positive Bacillus genera predominated under aerobic conditions with a small composition of the Gram-negative Microbacterium sp. More biodiversity was observed in anaerobic cultures with the marked appearance of Enterococcus, Arthrobacter, Paenibacillus and Oceanobacillus species. Experiments run on purified individual species did not achieve the same level of $\mathrm{Cr}(\mathrm{VI})$ reduction as observed in the original consortium from sludge indicating possible existence of interspecies interactions necessary for optimum $\mathrm{Cr}(\mathrm{VI})$ reduction. All $\mathrm{Cr}$ (VI) reduced was accounted for as $\mathrm{Cr}(\mathrm{III})$ with a small error range (2-6\%).

(c) 2008 Elsevier Ltd. All rights reserved.
\end{abstract}

\section{Introduction}

Hexavalent chromium [Cr(VI)] compounds are used in a wide variety of commercial processes and unregulated disposal of chromium containing effluents has led to the contamination of soil, aquatic sediments, and surface and groundwater environments. Chromium, a steel-grey, lustrous, hard and brittle metal, occurs in nature in the bound form that constitutes $0.1-0.3 \mathrm{mg} / \mathrm{kg}$ of the Earth's crust. It has several oxidation states ranging from $(-\mathrm{II})$ to $(+\mathrm{VI})$, the trivalent and hexavalent states being the most stable. A maximum acceptable concentration of $50 \mu \mathrm{g} / \mathrm{L}$ for $\mathrm{Cr}(\mathrm{VI})$ in drinking water has been established on the basis of health considerations (Kiilunen, 1994). In some American states, the exposure limit for $\mathrm{Cr}(\mathrm{VI})$ is as low as $15 \mu \mathrm{g} / \mathrm{L}$ for humans and $10 \mu \mathrm{g} / \mathrm{L}$ for aquatic organisms (Levitskaia et al., 2008) which is below the detection limit for most low cost colorimetric methods. $\mathrm{Cr}(\mathrm{VI})$ concentrations above the allowable limit cause cancer in humans and aquatic fauna, and is acutely toxic at much higher concentrations (U.S.EPA, 1978; Federal Register, 2004).

$\mathrm{Cr}(\mathrm{VI})$ is discharged into the environment through anthropogenic activities such as chromite ore processing,

* Corresponding author. Water Utilisation Division, Department of Chemical Engineering, University of Pretoria, South Campus, Building No. 2, Pretoria 0002, South Africa. Tel.: +2712 420 5894; fax: +2712 3625089.

E-mail address: evans.chirwa@up.ac.za (E.M. Nkhalambayausi-Chirwa). 0043-1354/\$ - see front matter @ 2008 Elsevier Ltd. All rights reserved. doi:10.1016/j.watres.2008.07.040 


$\begin{array}{ll}\text { Nomenclatures } \\ C & \mathrm{Cr}(\mathrm{VI}) \text { concentration at time } t\left(\mathrm{ML}^{-3}\right) \\ \mathrm{C}_{\mathrm{O}} & \text { initial } \mathrm{Cr}(\mathrm{VI}) \text { concentration }\left(\mathrm{ML}^{-3}\right) \\ \mathrm{R}_{\mathrm{C}} & \mathrm{Cr}(\mathrm{VI}) \text { reduction capacity }\left(\mathrm{MM}^{-1}\right) \\ \mathrm{X} & \text { viable cell concentration at time } t\left(\mathrm{ML}^{-3}\right) \\ \mathrm{X}_{\mathrm{O}} & \text { initial viable cell concentration }\left(\mathrm{ML}^{-3}\right)\end{array}$

electroplating, corrosion control, wood preservation and leather-tanning processes, among others (Chuan and Liu, 1996; Palmer and Wittbrodt, 1991; Lawson, 1997). In most $\mathrm{Cr}(\mathrm{VI})$ contaminated sites in South Africa, the problem is exacerbated by the existence of abandoned and closed mining or processing operations. Current methods of environmental remediation of $\mathrm{Cr}(\mathrm{VI})$ include the pump-and-treat method in which chemical processes that involve the adjustment of $\mathrm{pH}$ using strong acids and bases are utilised in the treatment of $\mathrm{Cr}(\mathrm{VI})$. Chemical processes often generate other harmful byproducts that require further treatment (Patterson, 1985). Biological processes offer a cleaner cost effective alternative that can be carried out under a natural $\mathrm{pH}$ range (6.8-7.2).

Microbial $\mathrm{Cr}(\mathrm{VI})$ reduction was first reported in the late 1970s when Romanenko and Koren'kov (1977) observed Cr(VI) reduction capability in Pseudomonas spp. grown under anaerobic conditions. Since then, several researchers have isolated new microorganisms that catalyse $\mathrm{Cr}(\mathrm{VI})$ reduction under varying conditions (Ackerley et al., 2004; Chirwa and Wang, 1997a; Ohtake et al., 1990; Ganguli and Tripathi, 2002; Suzuki et al., 1992; Ramírez-Ramírez et al., 2004; Shen and Wang, 1993; Baldi et al., 1990). Other researchers have also observed $\mathrm{Cr}(\mathrm{VI})$ reduction in consortium cultures isolated from the environment (Chirwa and Wang, 2000; Stasinakis et al., 2004; Dermou et al., 2005; Chen and Gu, 2005; Chang and Kim, 2007). $\mathrm{Cr}(\mathrm{VI})$ reduction has been demonstrated to be cometabolic (not participating in energy conservation) in certain species of bacteria, but is predominantly dissimilatory/respiratory under anaerobic conditions (Ishibashi et al., 1990). In the latter process, $\mathrm{Cr}(\mathrm{VI})$ serves as a terminal electron acceptor in the membrane electron-transport respiratory pathway, a process resulting in energy conservation for growth and cell maintenance (Horitsu et al., 1987; Lovley and Phillips, 1994).

$\mathrm{Cr}(\mathrm{VI})$ reduction by microorganisms often results in consumption of large amounts of proton as reducing equivalents which results in the elevation of the background $\mathrm{pH}$. The increased $\mathrm{pH}$ facilitates the precipitation of the reduced chromium as chromium hydroxide, $\mathrm{Cr}(\mathrm{OH})_{3}(\mathrm{~s})$ as shown in Eqs. (1) and (2) below (Brock and Madigan, 1991; Zakaria et al., 2007):

$$
\mathrm{CrO}_{4}^{2-}+8 \mathrm{H}^{+} \stackrel{\mathrm{CRB}}{\longrightarrow} \mathrm{Cr}^{3+}+4 \mathrm{H}_{2} \mathrm{O} \stackrel{\text { neutral pH }}{\longrightarrow} \mathrm{Cr}(\mathrm{OH})_{3}(\mathrm{~s})+3 \mathrm{H}+\mathrm{H}_{2} \mathrm{O}
$$

$$
\begin{aligned}
3 \mathrm{CH}_{3} \mathrm{COO}^{-} & +4 \mathrm{HCrO}_{4}^{-}+4 \mathrm{CrO}_{4}^{2-}+33 \mathrm{H}^{+} \rightarrow 8 \mathrm{Cr}^{3+} \\
& +6 \mathrm{HCO}_{3}^{-}+20 \mathrm{H}_{2} \mathrm{O}
\end{aligned}
$$

Eq. (1) illustrates the general biological $\mathrm{Cr}(\mathrm{VI})$ reduction by $\mathrm{Cr}(\mathrm{VI})$ reducing bacteria (CRB) reconstructed from redox half reactions whereas Eq. (2) illustrates a typical reaction under anaerobic conditions using acetic acid as a carbon source and electron donor. Other fatty acid by-products of hydrolysis can also serve as electron donors for $\mathrm{Cr}(\mathrm{VI})$ reduction (Viamajala et al., 2006).

In this study, a high performing mixed-culture of bacteria was isolated from dried sludge at a wastewater treatment plant in Brits (SA). The culture achieved reduction rates three to 8 times higher than those observed in cultures studied elsewhere (Ohtake et al., 1990; Shen and Wang, 1994a; Chirwa and Wang, 1997a,b). In order to determine the reason for the observed exceptionally high $\mathrm{Cr}(\mathrm{VI})$ reduction rates, the cultures were purified and characterised to determine the species composition. The research is part of an effort to develop the bioremediation process for treatment of $\mathrm{Cr}(\mathrm{VI})$ contaminated sites in South Africa. Since 1940, South Africa has produced $72 \%$ of the world's chrome ore, the majority of which is mined in the North Eastern region of the country formally known as Transvaal (U.S.EPA, 2001; Mintek, 2004).

\section{Materials and methods}

\subsection{Culture and media}

\subsubsection{Source of microorganisms}

The mixed-culture of bacteria was obtained from dried sludge collected from sand drying beds at the Brits Wastewater Treatment Works (NW). The treatment plant receives periodic flows from a nearby abandoned sodium dichromate (SDC) processing facility reported to discharge high levels of $\mathrm{Cr}(\mathrm{VI})$ in the sewerage works. The chrome processing facility was commissioned as early as 1996. The measured $\mathrm{Cr}(\mathrm{VI})$ concentration in the influent and mixed liquor from the treatment plant was 2.45 and $2.63 \mathrm{mg} / \mathrm{L}$, respectively, and the $\mathrm{Cr}(\mathrm{VI})$ content in dried sludge was $25.44 \mathrm{~g} / \mathrm{m}^{3}$ at the time of sampling. Higher values of the reduced form of total $\mathrm{Cr}$ were expected in the mixed liquor and dry sludge due to the presence of $\mathrm{Cr}(\mathrm{VI})$ reducing bacteria. High $\mathrm{Cr}(\mathrm{VI})$ loadings from nearby chrome foundries are periodically discharged to the treatment plant, but the times at which microbial samples were collected for this study did not coincide with the discharge events. The sludge cultures were cultivated for 4 days at $30 \pm 1{ }^{\circ} \mathrm{C}$ in $100 \mathrm{~mL}$ of sterile Luria-Bettani (LB) broth containing varied concentrations of $\mathrm{Cr}(\mathrm{VI})$. Aerobic cultures were grown in $1 \mathrm{~L}$ Erlenmeyer flasks covered with cotton plugs, in suspension by agitation at $120 \mathrm{rpm}$ using a Labcon SPL-MP 15 Lateral Shaker (Labcon Laboratory Services, South Africa). Anaerobic cultures were grown in $100 \mathrm{~mL}$ serum bottles, sealed after purging for 5-10 min with 99\% pure nitrogen gas. All media were autoclaved for $15 \mathrm{~min}$ at $121^{\circ} \mathrm{C}$ and cooled to room temperature before use. Agar used for colony development was cooled to $40^{\circ} \mathrm{C}$ before use.

\subsubsection{Culture isolation}

Pure cultures were prepared by depositing $1 \mathrm{~mL}$ of a serially diluted sample on LB agar followed by incubation at $30^{\circ} \mathrm{C}$ to develop separate identifiable colonies. Individual colonies were transferred using a heat-sterilised wire loop into $100 \mathrm{~mL}$ sterile LB broth spiked with $75 \mathrm{mg} \mathrm{Cr}(\mathrm{VI}) / \mathrm{L}$. The cells were allowed to grow; colonies were grown again from serially diluted samples. Loop-fulls from individual colonies were used to inoculate fresh media containing $150 \mathrm{mg} \mathrm{Cr}(\mathrm{VI}) / \mathrm{L}$. 
Cultures from the third isolation were used in the detailed $\mathrm{Cr}(\mathrm{VI})$ reduction rate analysis. $\mathrm{Cr}(\mathrm{VI})$ reducing colonies were selected by observing complete $\mathrm{Cr}(\mathrm{VI})$ reduction after incubation for $72 \mathrm{~h}$. The selected colonies were stored at $4{ }^{\circ} \mathrm{C}$ in test tube slant cultures or agar-plate streaks.

\subsubsection{Culture characterisation}

Phylogenetic characterisation of cells was performed on individual colonies of bacteria from the $7^{\text {th }}$ to 10 th tube in the serial dilution preparation. LB and Plate Count (PC) agar was used for colony development. In preparation for the 16S rRNA sequence identification, the colonies were first classified based on morphology. Seven different morphologies were identified for the aerobic cultures (19 morphologies for the aerobic cultures). These were streaked on nutrient agar followed by incubation at $37^{\circ} \mathrm{C}$ for $18 \mathrm{~h}$.

Genomic DNA was extracted from the pure cultures using a DNeasy tissue kit (QIAGEN Ltd, West Sussex, UK) as per manufacturer's instructions. The 16S rRNA genes of isolates were amplified by reverse transcriptase-polymerase chain reaction (RT-PCR) using primers $\mathrm{pA}$ and $\mathrm{pH} 1$ (Primer $\mathrm{pA}$ corresponds to position 8-27; Primer $\mathrm{pH}$ to position 1541-1522 of the $16 \mathrm{~S}$ gene) (Coenye et al., 1999). An internal primer pD was used for sequencing (corresponding to position 519-536 of the $16 \mathrm{~S}$ gene). The resulting sequences were matched to known bacteria in the GenBank using a basic BLAST search of the National Centre for Biotechnology Information (NCBI, Bethesda, MD).

\section{2. $\mathrm{Cr}(\mathrm{VI})$ reduction experiments}

\subsubsection{Abiotic controls}

Killed culture cells and azide exposed cultures were used to determine the extent of abiotic $\mathrm{Cr}(\mathrm{VI})$ reduction in the batch experiments. Overnight grown cells were heat-killed by autoclaving at $121^{\circ} \mathrm{C}$ for $30 \mathrm{~min}$. Another set of overnight grown cells was subjected to azide toxicity by incubating the cells in a broth consisting of $0.1 \%$ azide solution using sodium azide $\left(\mathrm{NaN}_{3}\right)$ (Ginestet et al., 1998).

\subsubsection{Aerobic culture experiments}

Aerobic $\mathrm{Cr}(\mathrm{VI})$ reduction experiments were conducted in $100 \mathrm{~mL}$ Erlenmeyer flasks using cells harvested after $24 \mathrm{~h}$ incubation, concentrated by a ratio of $4: 1$, resulting in an average viable cell concentration of $5.2 \pm 2.1 \times 10^{9}$ cells $/ \mathrm{mL}$. The cells were washed twice by centrifugation and resuspension in a sterile solution of $0.085 \% \mathrm{NaCl}$ before adding $\mathrm{Cr}(\mathrm{VI})$. The batches were covered with cotton plugs during incubation to allow aeration while filtering away microorganisms from the air. $\mathrm{Cr}(\mathrm{VI})$ concentration in the range of $50-600 \mathrm{mg} / \mathrm{L}$ was added and the solution was incubated under shaking at $30^{\circ} \mathrm{C}$. Experimental units consisted of the different initial concentrations and all experiments were conducted in duplicate. Samples $(1 \mathrm{~mL})$ were withdrawn at time intervals determined by the observed rate of $\mathrm{Cr}(\mathrm{VI})$ removal. The samples were centrifuged at $2820 \mathrm{~g}(6000 \mathrm{rpm}, 7 \mathrm{~cm}$ rotor radius) for $10 \mathrm{~min}$ in a Hermle 2323 centrifuge (Hermle Laboratories, Wehigen, Germany) to remove suspended cells before analysis.

\subsubsection{Anaerobic culture experiments}

Anaerobic $\mathrm{Cr}(\mathrm{VI})$ reduction experiments were conducted in $100 \mathrm{~mL}$ serum bottles using cells harvested after $24 \mathrm{~h}$ incubation under anaerobic conditions. The cells were transferred under an anaerobic glove bag purged with $99.99 \% \mathrm{~N}_{2}$ gas. The cells were concentrated to a $4: 1$ ratio, and washed twice in a sterile solution of $0.085 \% \mathrm{NaCl}$ before adding $\mathrm{Cr}(\mathrm{VI})$. The bottles were purged with nitrogen gas $(99.99 \%)$ for $10 \mathrm{~min}$ to expel any residual oxygen before sealing with silicon stoppers and aluminium seals. After sealing, the cultures were incubated at $30 \pm 1{ }^{\circ} \mathrm{C}$ for 7 days. Samples $(1 \mathrm{~mL})$ were withdrawn using a sterile syringe at time intervals determined by the observed rate of $\mathrm{Cr}(\mathrm{VI})$ removal. The samples were centrifuged at $2820 \mathrm{~g}$ for $10 \mathrm{~min}$ in a Hermle 2323 centrifuge (Hermle Laboratories) to remove suspended cells before analysis. Headspace gases were sampled by syringe and analysed by gas chromatography.

\subsubsection{Cell free extracts and membrane fragments}

Pure cultures isolated in this study were grown in $500 \mathrm{~mL}$ for $24 \mathrm{~h}$ in sterile LB broth. The cells were then harvested by centrifugation at $2820 \mathrm{~g}$ for $10 \mathrm{~min}$. Pellets formed at the bottom of the centrifuge tubes were washed 2 times with sterile $0.85 \% \mathrm{NaCl}$ solution. The washed pellets were re-suspended at 2-3 g wet weight per $10 \mathrm{~mL}$ sterile $0.85 \% \mathrm{NaCl}$. Cells were disrupted by a $3 \mathrm{~mm}$ diameter microtip mounted to the Model VCX 500 Sonics VibraCell (Sonics \& Materials, Inc., Newtown, CT). The tubes containing concentrated cells were placed inside an ice container to avoid overheating during sonication. The tip was cleaned with ethanol and dried thoroughly before use. The cells were sonicated in four cycles of 15 min with 5 min rests between cycles.

The disrupted cells were centrifuged at $11,300 \mathrm{~g}$ for $20 \mathrm{~min}$ to extract the membrane fraction pellet from the disrupted cell mixture. The pellet was re-suspended into a $100 \mathrm{mg} \mathrm{Cr}(\mathrm{VI}) /$ $\mathrm{L}$ batch. The supernatant poured out from the centrifuge bottle was filled to $100 \mathrm{~mL}$ and $\mathrm{Cr}(\mathrm{VI})$ was added to prepare the second experimental batch of $100 \mathrm{mg} \mathrm{Cr}(\mathrm{VI}) / \mathrm{L}$ to evaluate $\mathrm{Cr}(\mathrm{VI})$ reduction by the cytoplasmic component of the cells.

\subsection{Analytical methods}

\subsection{1. $\mathrm{Cr}$ (VI) and total $\mathrm{Cr}$}

$\mathrm{Cr}$ (VI) was measured using a UV/vis spectrophotometer (WPA, Light Wave II, Labotech, South Africa). The measurement was carried out at a wavelength of $540 \mathrm{~nm}$ (10 mm light path) after acidification of $0.2 \mathrm{~mL}$ samples with $1 \mathrm{~N} \mathrm{H}_{2} \mathrm{SO}_{4}$ and reaction with 1,5-diphenyl carbazide to produce a purple colour (APHA, 2005). Total Cr was measured at a wavelength of $359.9 \mathrm{~nm}$ using a Varian AA - 1275 Series Flame Atomic Adsorption Spectrophotometer (AAS) (Varian, Palo Alto, CA (USA)) equipped with a $3 \mathrm{~mA}$ chromium hollow cathode lamp. Before analysis using the AAS, $10 \mathrm{~mL}$ samples were acidified with $1 \mathrm{~mL} 1 \mathrm{~N} \mathrm{H}_{2} \mathrm{SO}_{4}$ to dissolve chromium hydroxide precipitates and to extract adsorbed $\mathrm{Cr}(\mathrm{VI})$. $\mathrm{Cr}$ (III) was determined as the difference between total $\mathrm{Cr}$ and $\mathrm{Cr}(\mathrm{VI})$ concentration.

\subsubsection{Dry weight of biomass}

LB broth $(5 \mathrm{~mL})$ containing grown cells was withdrawn by sterile pipette after $24 \mathrm{~h}$ of incubation at $30^{\circ} \mathrm{C}$ and filtered 
through a washed, dried and weighed sintered glass (tare weight). The sintered glass and wet biomass was dried in the oven at $105^{\circ} \mathrm{C}$, cooled in a desiccator and weighed. The drying, cooling and weighing was carried out until a constant dry weight was obtained. The dry weight of the biomass in $5 \mathrm{~mL}$ was calculated as the difference in weight between that of the sintered glass plus biomass and that of the empty sintered glass. The dry weight of the biomass per liter was obtained by extrapolation from the $5 \mathrm{~mL}$ volume.

\subsubsection{Viable biomass}

Viable cells were determined using the pour plate method using heterotrophic (pour) plate method and colony counts as described in the Standard Methods for the Examination of Water and Wastewater (APHA, 2005), with the colonies grown on Luria-Bettani (LB) and Plate Count (PC) agar. Samples for the analysis of viable suspended cell concentration were withdrawn from experimental batches at 6-12 h intervals. Samples $(1 \mathrm{~mL})$ were serially diluted in $0.9 \mathrm{~mL}$ sterile $0.85 \% \mathrm{NaCl}$ solution. Each dilution $(1 \mathrm{~mL})$ was then added to agar plates $(100 \mathrm{~cm} \times 15 \mathrm{~cm}$ size) followed by thorough mixing with approximately $10 \mathrm{~mL}$ of liquid agar at $46^{\circ} \mathrm{C}$. Colonies were counted after $24 \mathrm{~h}$ incubation and the bacterial count was reported as colony forming units (CFU) per $\mathrm{mL}$ of sample. The CFU count was converted to mass concentration by measuring dry weight of cells with a known CFU count during the log growth phase when over $95 \%$ of the cells were expected to be viable. A conversion factor of $1.833 \times 10^{-10} \mathrm{mg} / \mathrm{cell}$ was determined (with $R^{2}=0.997$ ). The inactivated mass concentration of viable cells was used to determine the $\mathrm{Cr}(\mathrm{VI})$ reduction capacity of the cells $\left(R_{c}\right)$.

\subsection{4. $\quad \operatorname{Cr}(\mathrm{VI})$ reduction capacity}

The $\mathrm{Cr}(\mathrm{VI})$ reduction capacity of the cells was determined as the amount of $\mathrm{Cr}(\mathrm{VI})$ reduced per amount of viable cells inactivated during incubation (Shen and Wang, 1994b):

$R_{c}=\frac{C_{o}-C}{X_{o}-X}$

where $R_{c}=\mathrm{Cr}(\mathrm{VI})$ reduction capacity (mg Cr(VI) removed $/ \mathrm{mg}$ cells inactivated), $C_{o}=$ initial $\mathrm{Cr}(\mathrm{VI})$ concentration $(\mathrm{mg} / \mathrm{L})$, $\mathrm{C}=\mathrm{Cr}(\mathrm{VI})$ concentration at a time of incubation $t, \mathrm{X}_{\mathrm{o}}=$ initial viable cell concentration $(\mathrm{mg} / \mathrm{L})$, and $\mathrm{X}=$ viable cell concentration $(\mathrm{mg} / \mathrm{L})$ at any time $t$. A viable cell conversion factor of $1.833 \times 10^{-10} \mathrm{mg} /$ cell was used to convert cell count (CFU) to the mass concentration.

\section{Results and discussion}

\subsection{Preliminary studies}

\subsection{1. $\mathrm{Cr}(\mathrm{VI})$ reducing bacteria}

A survey was conducted which involved collection and testing cultures from four different sources for $\mathrm{Cr}(\mathrm{VI})$ reduction, i.e., soil from a contaminated site, influent to sewage treatment plant, activated sludge tanks (mixed liquor), and dry sludge from sand drying beds. The bacteria from the above sources was incubated for $96 \mathrm{~h}$ in LB broth at initial concentrations of 20, 50, 100, 150, 200, 300, 400 and $600 \mathrm{mg} \mathrm{Cr}(\mathrm{VI}) / \mathrm{L}$ under aerobic conditions (Fig. 1). Existence of $\mathrm{Cr}(\mathrm{VI})$ reducing bacteria in the samples was indicated by observed removal rates as shown in the figure. The highest removal rate was observed in the culture from dried sludge with near complete $\mathrm{Cr}(\mathrm{VI})$ removal observed in batches up to $300 \mathrm{mg} \mathrm{Cr}(\mathrm{VI}) / \mathrm{L}$. This was attributed to better acclimation and selection for $\mathrm{Cr}(\mathrm{VI})$ reducing species in the sludge due to exposure to higher $\mathrm{Cr}(\mathrm{VI})$ concentrations and longer exposure in the sludge zone than in the mixed liquor. The culture isolated from soil yielded the lowest $\mathrm{Cr}(\mathrm{VI})$ removal rate. Very low to insignificant $\mathrm{Cr}(\mathrm{VI})$ reduction was observed at very high initial $\mathrm{Cr}(\mathrm{VI})$ concentration of $600 \mathrm{mg} / \mathrm{L}$ except for the dry sludge culture where $18.7 \%$ was removed after incubation for $96 \mathrm{~h}$. This was attributed to the inhibition effect of $\mathrm{Cr}(\mathrm{VI})$ on the culture.

\subsubsection{Test for abiotic $\mathrm{Cr}(\mathrm{VI})$ reduction}

Abiotic $\mathrm{Cr}$ (VI) reduction activity was evaluated by conducting experiments at $100 \mathrm{mg} \mathrm{Cr}(\mathrm{VI}) / \mathrm{L}$ with heat-killed and azide inhibited cultures (Fig. 2). A live cell culture control showed best performance with near complete $\mathrm{Cr}(\mathrm{VI})$ removal at $22.5 \mathrm{~h}$. There was significant decrease in $\mathrm{Cr}(\mathrm{VI})$ reduction activity due to heat inactivation of the cells. Only $30 \% \mathrm{Cr}$ (VI) removal was observed in heat-killed cultures after incubation for $22.5 \mathrm{~h}$, a much lower removal value than that observed in the live consortium. The $30 \%$ removal may be due to $\mathrm{Cr}(\mathrm{VI})$ reductase released into the medium from heat-lysed cells and regrowth of cells that escaped destruction by heat. An azide inhibited culture indicated partial inactivation of cells with an observed $\mathrm{Cr}(\mathrm{VI})$ reduction potential of the oxygen stressed culture. Approximately $50 \% \mathrm{Cr}(\mathrm{VI})$ was removed in the azide inhibited cultures.

\section{2. $\operatorname{Cr}(\mathrm{VI})$ reduction under aerobic conditions}

Experimentation under varying initial $\mathrm{Cr}(\mathrm{VI})$ concentration of $50-400 \mathrm{mg} / \mathrm{L}$ in media with harvested and concentrated cells showed that the culture achieved complete $\mathrm{Cr}(\mathrm{VI})$ removal in

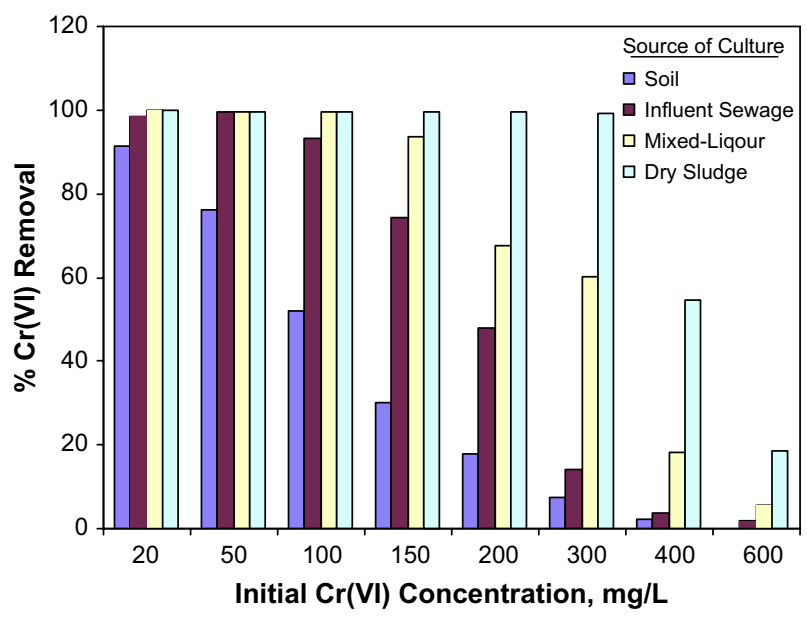

Fig. 1 - $\mathrm{Cr}$ (VI) reduction in cultures from different sources (soil, influent stream, mixed liquor, and dry sludge) after incubation for $96 \mathrm{~h}$ under varying initial $\mathrm{Cr}(\mathrm{VI})$ concentration and growing cells (inoculated with $5 \times 10^{4} \mathrm{CFU} / \mathrm{mL}$ before incubation). 


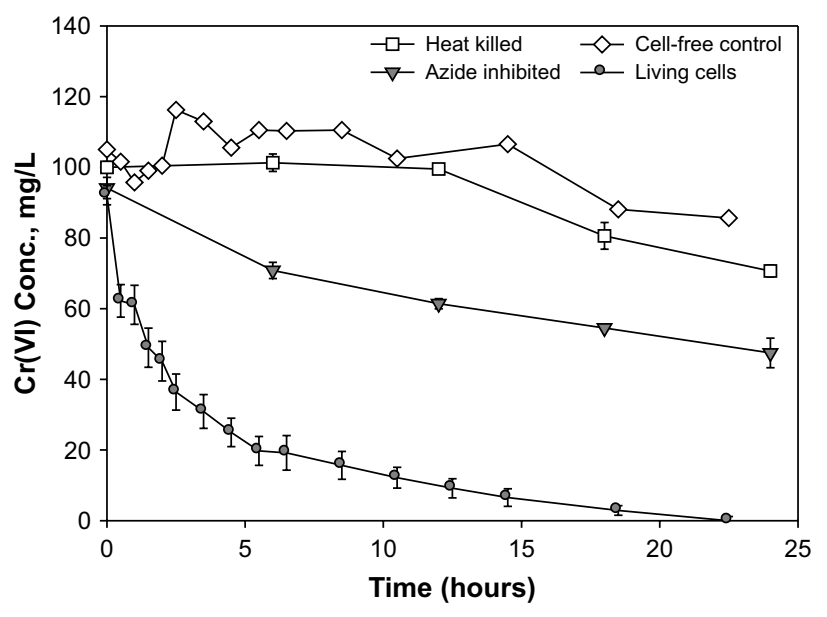

Fig. 2 - Evaluation of abiotic $\mathrm{Cr}(\mathrm{VI})$ reduction in heat-killed and azide inhibited cells (inoculated with $5 \times 10^{4} \mathrm{CFU} / \mathrm{mL}$ before incubation).

batches under initial concentration up to $200 \mathrm{mg} / \mathrm{L}$ in less than $64.3 \mathrm{~h}$ (2.7 days) (Fig. 3). Up to $94 \%$ of $\mathrm{Cr}(\mathrm{VI})$ was removed at the initial concentration of $300 \mathrm{mg} / \mathrm{L}$ after incubation for $110 \mathrm{~h}$. Very little $\mathrm{Cr}(\mathrm{VI})$ was reduced at the highest concentration tested (400 mg/L). The loss of the capability to reduce $\mathrm{Cr}(\mathrm{VI})$ in cells under very high $\mathrm{Cr}(\mathrm{VI})$ loadings was directly correlated to the loss of cell viability. Viable cell concentration in the $400 \mathrm{mg} / \mathrm{L}$ batches decreased from $5.2 \pm 2.0 \times 10^{9}$ to $4.8 \pm 1.5 \times$ $10^{5}$ cells $/ \mathrm{mL}$ after $22.5 \mathrm{~h}$ incubation, a kill rate of $4.1 \mathrm{log}$, whereas the kill rate at lower concentration of $100 \mathrm{mg} / \mathrm{L}$ was only $1.2 \log \left(6.1 \pm 1.8 \times 10^{9}-3.81 \pm 1.5 \times 10^{8}\right.$ cells $\left./ \mathrm{mL}\right)$. This was in agreement with earlier observations in previous studies where $\mathrm{Cr}(\mathrm{VI})$ reducing cells were irreversibly inactivated in batch cultures when the initial concentration exceeded a certain limiting concentration (Wang and Shen, 1997). These results demonstrate that $\mathrm{Cr}(\mathrm{VI})$ reduction is significantly

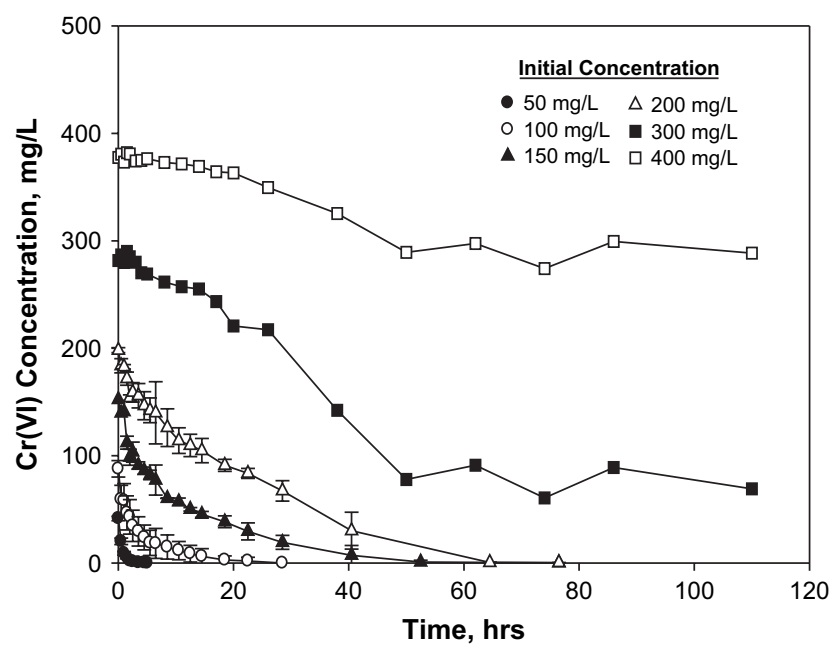

Fig. 3 - Aerobic culture experiment of $\mathrm{Cr}(\mathrm{VI})$ reduction in consortium from dried sludge grown at initial $\mathrm{Cr}(\mathrm{VI})$ concentrations ranging from 50 to $600 \mathrm{mg} / \mathrm{L}$ (resting cells: $5.2 \pm 2.1 \times 10^{9} \mathrm{CFU} / \mathrm{mL}$ ). affected by the $\mathrm{Cr}(\mathrm{VI})$ toxicity. Based on the highest concentration completely removed, i.e., $200 \mathrm{mg} / \mathrm{L}$ batch, the $R_{\mathrm{c}}$ value of $0.21 \mathrm{mg} \mathrm{Cr}(\mathrm{VI})$ reduced/mg cells deactivated was determined. This value is much higher than the values previously reported in literature (Shen and Wang, 1994b; Nkhalambayausi-Chirwa and Wang, 2005).

\subsubsection{Fate of $\mathrm{Cr}(\mathrm{VI})$ [mass balance]}

Biotransformation of $\mathrm{Cr}$ (VI) to $\mathrm{Cr}$ (III) was validated by a mass balance analysis on $\mathrm{Cr}$ species during incubation. Since $\mathrm{Cr}(\mathrm{VI})$ was the only added form of $\mathrm{Cr}$, the total $\mathrm{Cr}$ measured using the AAS at the end of the experiment was expected to be equal to the amount of $\mathrm{Cr}(\mathrm{VI})$ added. The added $\mathrm{Cr}(\mathrm{VI})$ in all batches was accounted for as total $\mathrm{Cr}$ at the end of the experiment with measurement errors within the $\pm 5 \%$ range. Only one value (at $100 \mathrm{mg} / \mathrm{L}$, error $=+8 \%$ ) exceeded the acceptable error range of $\pm 5 \%$.

\section{3. $\quad \mathrm{Cr}(\mathrm{VI})$ reduction in an anaerobic mixed-culture}

$\mathrm{Cr}(\mathrm{VI})$ reduction under anaerobic conditions was investigated due to its relevance to certain applications such as bioremediation of sediment zones and groundwater environments. The experiment under anaerobic conditions was conducted over a lower concentration range (50-300 mg $\mathrm{Cr}(\mathrm{VI}) / \mathrm{L})$ since slower growth was observed in the anaerobic cultures. The rate of $\mathrm{Cr}$ (VI) reduction was generally slower in the anaerobic cultures. Complete $\mathrm{Cr}(\mathrm{VI})$ reduction occurred in cultures with a lower initial $\mathrm{Cr}(\mathrm{VI})$ concentration of $150 \mathrm{mg} / \mathrm{L}$ after a longer incubation period ( $155 \mathrm{~h}$ ) than in aerobic cultures (Fig. 4). These results indicate that the $\mathrm{Cr}(\mathrm{VI})$ reduction mechanism in the cells is either coupled to the metabolic processes of the culture or different species in the culture with different growth requirements are responsible for $\mathrm{Cr}(\mathrm{VI})$ reduction. Characteristic anaerobic gases $\left(\mathrm{CO}_{2}\right.$ and $\mathrm{H}_{2} \mathrm{O}$ vapour) accumulated in the headspace of the serum culture bottles. The amount of gas produced (determined by partial pressure) was lower at higher initial $\mathrm{Cr}(\mathrm{VI})$ concentration showing that gas

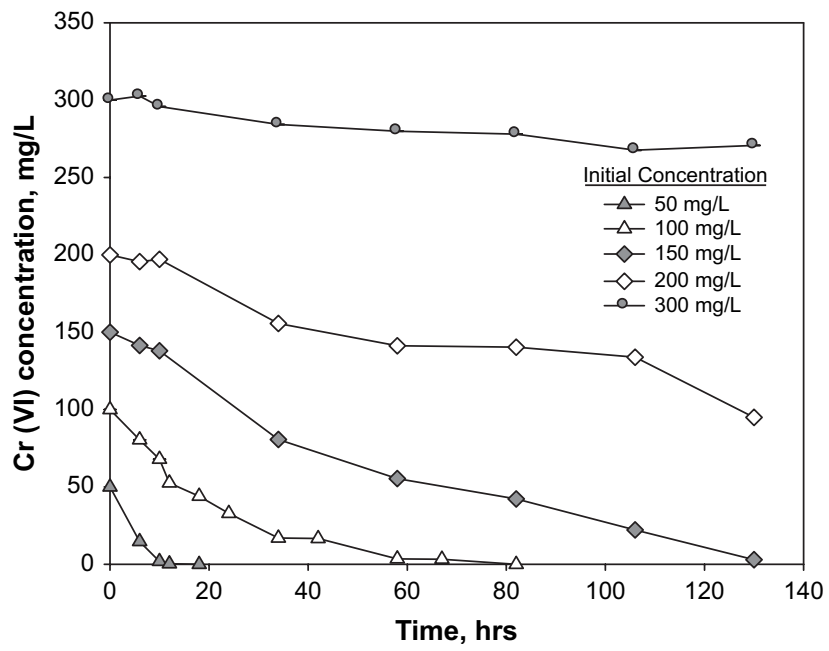

Fig. 4 - Anaerobic culture experiment of $\mathrm{Cr}(\mathrm{VI})$ reduction in consortium from dried sludge grown at initial $\mathrm{Cr}(\mathrm{VI})$ concentrations ranging from 50 to $300 \mathrm{mg} / \mathrm{L}$ (resting cells: $\left.1.58 \pm 1.8 \times 10^{9} \mathrm{CFU} / \mathrm{mL}\right)$. 

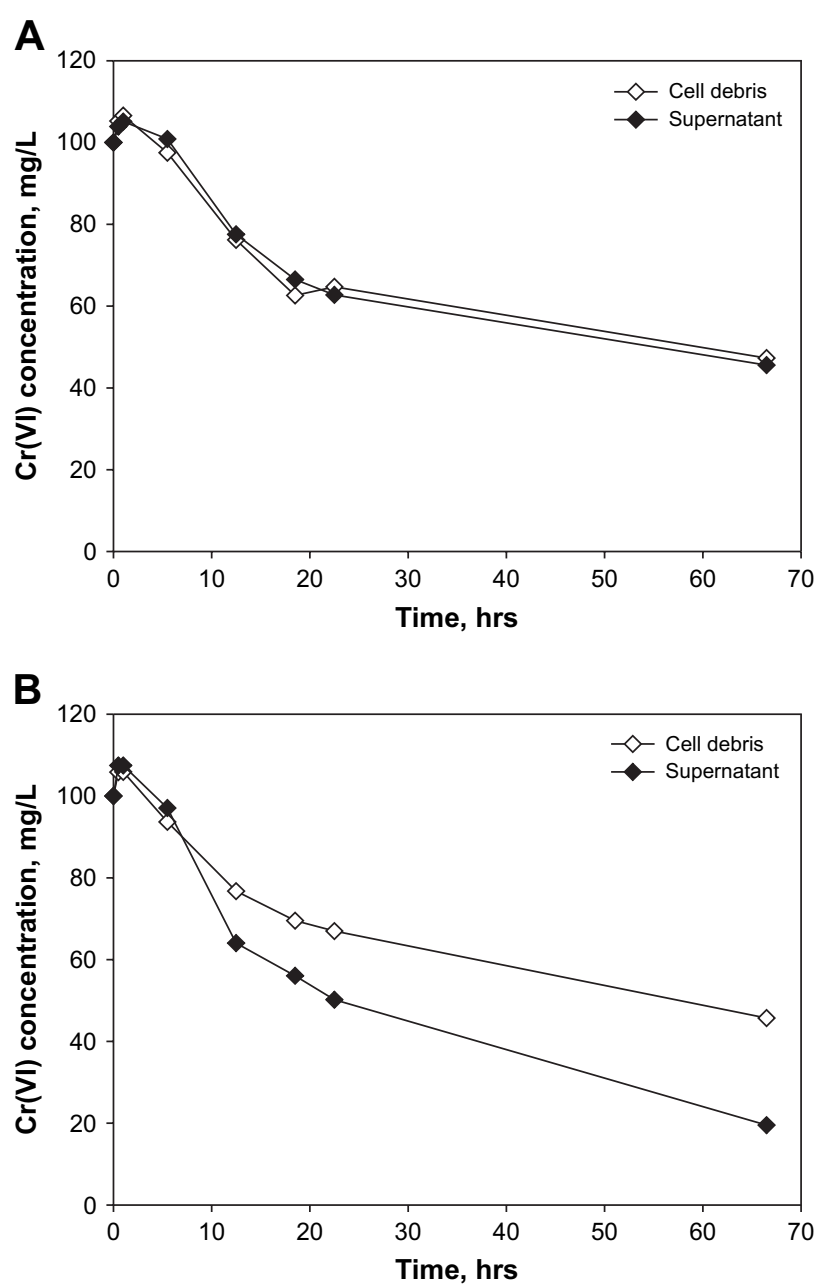

Fig. 5 - Cr(VI) reduction in disrupted (A) aerobically grown cells and (B) anaerobically grown cells showing the higher $\mathrm{Cr}(\mathrm{VI})$ reduction rate in the cytosolic component (supernatant) than in the membrane fraction (pellet) after centrifugation of disrupted cells at $11,300 \mathrm{~g}$ for $24 \mathrm{~min}$.

production was an essential component of the metabolic process and that it was inhibited by $\mathrm{Cr}(\mathrm{VI})$. For example, the anaerobic gas $\left(\mathrm{CO}_{2}\right)$ composition at an initial concentration of $50 \mathrm{mg} / \mathrm{L} \mathrm{N} \mathrm{N}_{2}$-purged reactors [88( \pm 2$) \% \mathrm{CO}_{2}, 6( \pm 3) \% \mathrm{H}_{2} \mathrm{O}$, and 4.3( \pm 2$) \% \mathrm{~N}_{2}$ ] was much higher than the composition at $300 \mathrm{mg} / \mathrm{L}\left[15.2( \pm 3) \% \mathrm{CO}_{2}, 2( \pm 3) \% \mathrm{H}_{2} \mathrm{O}\right.$, and $\left.78( \pm 1) \% \mathrm{~N}_{2}\right]$.

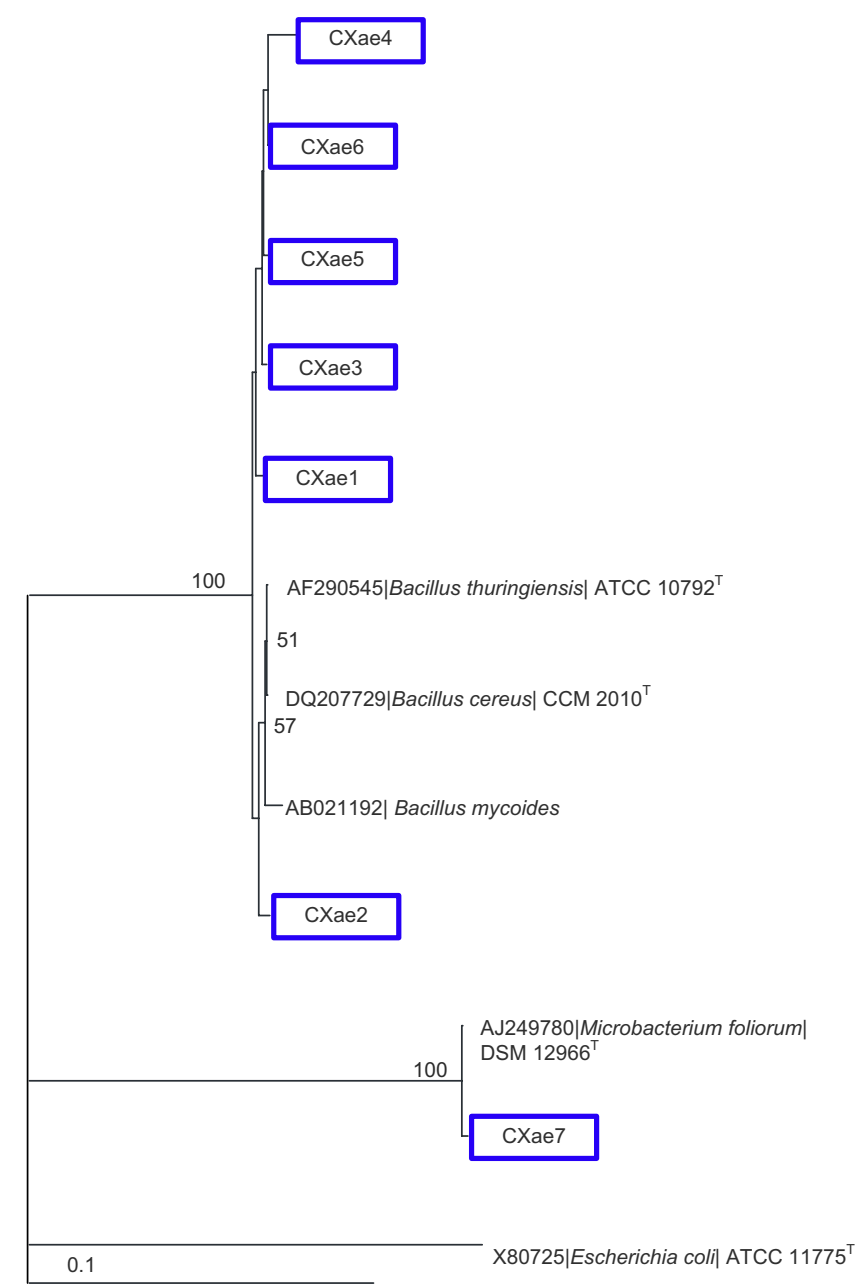

Fig. 6 - Phylogenetic tree of species from Brits dry sludge reflecting microbial diversity under aerobic conditions.

For the anaerobic batch experiments, $\mathrm{Cr}(\mathrm{VI})$ reduction was incomplete at $200 \mathrm{mg} / \mathrm{L}$ initial $\mathrm{Cr}(\mathrm{VI})$ concentrations after incubation for $130 \mathrm{~h}$ (only 50\% reduced). This was a much lower performance compared to the observed under the same concentration in aerobic cultures where $99.7 \%$ removal was achieved after $96 \mathrm{~h}$. The lower $\mathrm{Cr}(\mathrm{VI})$ removal rates observed under anaerobic conditions were accompanied by lower $\mathrm{Cr}(\mathrm{VI})$ reduction capacity of the cells $\left(R_{c}=0.011427 \mathrm{~g} \mathrm{Cr}(\mathrm{VI})\right.$ reduced/ g cells inactivated at $150 \mathrm{mg} / \mathrm{L}$ and $0.051697 \mathrm{~g} \mathrm{Cr}(\mathrm{VI})$ reduced/g

Table 1 - Partial sequencing of aerobic CRB isolated from Brits dry sludge grown in solution containing $100 \mathrm{mg} / \mathrm{L} \mathrm{Cr}(\mathrm{VI})$

Pure culture

Partial 16S ID ${ }^{\mathrm{a}}$

\% Identity

\begin{tabular}{lll}
\hline X1 & Bacillus cereus strain 213 16S, Bacillus thuringiensis 16S \\
X2 & Bacillus sp. ZZ2 16s, B. cereus ATCC 10987, B. thuringiensis str. Al Hakam & 99 \\
X3 & Bacillus sp. 32-661 16s, B. cereus strain 16S & 99 \\
X4 & Bacillus mycoides strain BGSC 6A13 16S, B. thuringiensis serovar finitimus strain BGSC 4B2 16S \\
X5 & B. mycoides strain BGSC 6A13 16S, B. thuringiensis serovar finitimus strain BGSC 4B2 16S \\
X6 & B. mycoides strain BGSC 6A13 16S, B. thuringiensis serovar finitimus strain BGSC 4B2 16S \\
X7 & Microbacterium sp. S15-M4, Microbacterium foliorum & 99 \\
\hline a S ID = 16 Svedburg rRNA Identity of partial sequences (16 Svedburg unit ribosomal Ribo-Nucleic-Acid Identity). & 99 \\
\hline
\end{tabular}

Please cite this article in press as: Pulane E. Molokwane et al., Chromium (VI) reduction in activated sludge bacteria exposed to high chromium loading: Brits culture (South Africa), Water Research (2008), doi:10.1016/j.watres.2008.07.040 
cells inactivated at $200 \mathrm{mg} / \mathrm{L}$ ). The $R_{c}$ value under anaerobic conditions was thus an order of magnitude lower than the value obtained from aerobically grown cultures from the same source.

\section{4. $\quad \operatorname{Cr}(\mathrm{VI})$ reduction pathway}

Cells were disrupted by ultrasonication to release the cytosol into the solution. This was done to allow direct access to the intracellular enzymes without the limitation of mass transport through the cellular membranes of the bacteria. This also meant that the cells would be killed in the process. The Cr(VI) reduction experiments were conducted on the supernatant and cell fragments collected as a pellet after centrifugation at $11,300 \mathrm{~g}$ for $20 \mathrm{~min}$ and re-suspended in medium for $\mathrm{Cr}(\mathrm{VI})$ reduction experiment. Results for the disrupted aerobic and anaerobic cultures are shown in Fig. 5.

The difference in the $\mathrm{Cr}(\mathrm{VI})$ reduction rate between the cytosolic component and the membrane fraction in the aerobic culture was insignificant (Fig. 5a). However, in the anaerobic culture, a higher removal rate was observed in the supernatant than in the membrane fraction - comparatively, the cytosolic component achieved 50\% removal in $24 \mathrm{~h}$, a much higher level than the observed $20-25 \%$ in the membrane fraction. Cell disruption was most effective in anaerobic cultures which resulted in a higher $\mathrm{Cr}(\mathrm{VI})$ reduction rate in the cytosolic component as evidenced by the higher $\mathrm{Cr}$ (VI) reduction in the diluted supernatant (Fig. 5b). It was later observed that, under aerobic conditions, cells were predominantly Gram-positive Bacilli. The Gram-positive cells are protected by a thick peptidoglycan cell wall expected to be difficult to disrupt.

It was interesting to note that the percentage removal rate in the cytosolic component of the crushed anaerobic culture was similar to the azide inhibited culture experiment whereby up to $50 \%$ removal was achieved in $22.5 \mathrm{~h}$. This may be due to the fact that enzymes that were produced during the cell cultivation process were still available for $\mathrm{Cr}(\mathrm{VI})$ reduction after the cell growth inhibitor was added. In heat-killed culture, enzymes were expected to be denatured and inactivated at high temperatures (between 50 and $80^{\circ} \mathrm{C}$ ), thus no $\mathrm{Cr}$ (VI) reduction activity was observed under these conditions.

\subsection{Culture characterisation}

\subsubsection{Aerobic cultures}

The natural consortium sampled from dried sludge from the Wastewater Treatment Works at Brits (NW) produced the higher $\mathrm{Cr}(\mathrm{VI})$ reduction rate. For this reason, the culture from the dry sludge was chosen for characterisation. Culture purification and 16S rRNA sequencing were performed at the Department of Microbiology, University of Pretoria where the identification was done; at 99\%, results indicated the predominance of four aerobe phenotypes.

Partial sequences of $16 \mathrm{~S}$ rRNA matched the Bacillus groups - Bacillus cereus ATCC 10987, B. cereus 213 16S, Bacillus thuringiensis (serovar finitimus), Bacillus mycoides - and two Microbacterium group - Microbacterium foliorum and Microbacterium sp. S15-M4 (Table 1). A phylogenetic tree was constructed for the species from purified cultures grown under aerobic conditions based on a basic BLAST search of rRNA sequences in the NCBI database (Fig. 6).

\subsection{Anaerobic culture}

Anaerobic bacteria was isolated from dry sludge following the same procedure described for aerobic cultures, modified by maintaining anaerobic conditions by purging reactors with

\section{Table 2 - Characteristics of pure cultures and nearest matches based on the BLAST analysis of 16S rRNA partial sequences}

$$
\text { Pure culture Colour on plates Blast result }
$$

\begin{tabular}{|c|c|c|c|c|}
\hline \multicolumn{5}{|c|}{ Chromium(VI) 100 mg/L } \\
\hline 1 & $\mathrm{X} 1$ & Light brown/cream & Could not subculture/amplify & \\
\hline 2 & $\mathrm{X} 2$ & Off-white & Enterococcus avium, Enterococcus pseudoavium & 99 \\
\hline 3 & $\mathrm{x} 3$ & Cream & Uncultured bacterium clone Y2, Acinetobacter sp. ANT9054 & 97 \\
\hline \multicolumn{5}{|c|}{ Chromium(VI) 150 mg/L } \\
\hline 4 & $\mathrm{X} 4$ & Coral & Could not subculture/amplify & \\
\hline 5 & $\mathrm{X} 5$ & Yellow & Could not subculture/amplify & \\
\hline 6 & x6a & Yellow & Arthrobacter sp. Sphe3, uncultured soil bacterium clone TA12 & 93,94 \\
\hline 7 & $\mathrm{x} 6 \mathrm{~b}$ & & Arthrobacter sp. AK-1 & 99 \\
\hline 8 & $\mathrm{X} 7$ & Cream \& yellow rings & Bacillus drentensis, B. drentensis & 96,97 \\
\hline 9 & $\mathrm{X} 8$ & Light brown & Could not subculture/amplify & \\
\hline 10 & X9 & Light brown & Could not subculture/amplify & \\
\hline 11 & $\mathrm{X} 10$ & Light brown & Oceanobacillus sp. JPLAk1, Virgibacillus necropolis & 99,98 \\
\hline 12 & $\mathrm{X} 11$ & Off-white & Enterococcus faecium strain R0026, Rumen bacterium R4-4 & 99 \\
\hline 13 & $\mathrm{X} 12$ & Coral & Paenibacillus pabuli, Paenibacillus xylanilyticus strain XIL14 & 99 \\
\hline \multicolumn{5}{|c|}{ Chromium(VI) 200 mg/L } \\
\hline 14 & $\mathrm{X} 13$ & Yellow & Could not subculture/amplify & \\
\hline 15 & $\mathrm{X} 14$ & Orange & Could not subculture/amplify & \\
\hline 16 & $\mathrm{X} 15$ & Cream & [Brevibacterium] frigoritolerans, Bacillus sp. R21S & 99 \\
\hline 17 & $\mathrm{X} 16$ & Yellow & Could not subculture/amplify & \\
\hline 18 & $\mathrm{X} 17$ & Cream & Uncultured bacterium, Bacillus sp. BS19 & 93 \\
\hline
\end{tabular}




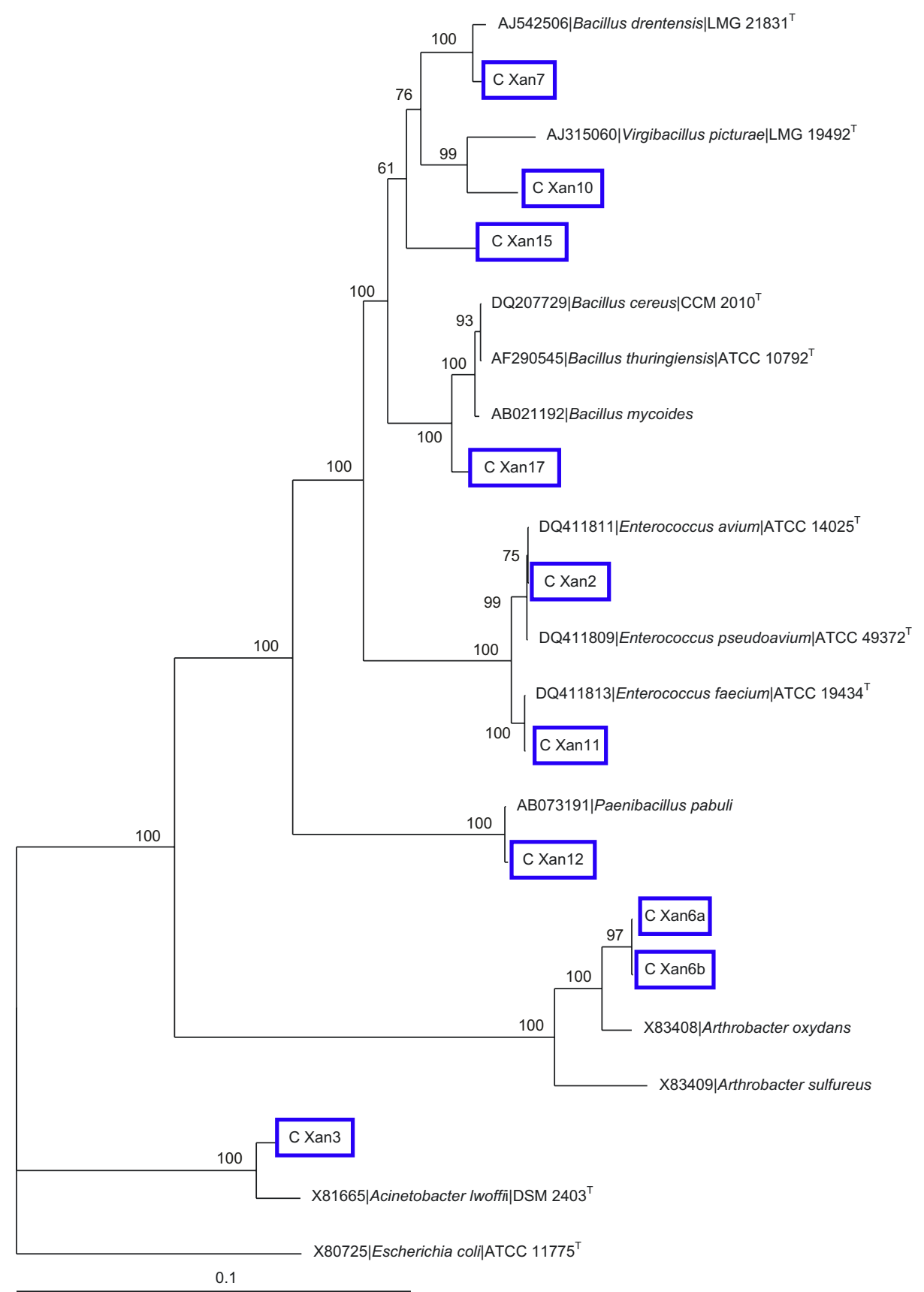

Fig. 7 - Phylogenetic tree of species from Brits dry sludge reflecting microbial diversity under anaerobic conditions.

nitrogen and sealing in serum bottles. All transfers were conducted in an anaerobic glove bag purged with nitrogen. The cultures were isolated under 100, 150 and $200 \mathrm{mg} \mathrm{Cr}(\mathrm{VI}) / \mathrm{L}$. Eighteen different morphologies were identified from anaerobic cultures (Table 2). Some of the bacteria were unculturable but produced a fingerprint during 16S rRNA analysis. Some were cultured but were marked as unidentified. Only 11 colonies from the anaerobic cultures were partially identified and seven colonies could not be amplified for partial gene sequencing.

Results indicated the predominance of eighteen anaerobic phenotypes. Partial sequences of $16 \mathrm{~S}$ rRNA matched the seven
Bacillus groups - Bacillus drentensis, Bacillus sp. BS19, Bacillus sp. R21S, Oceanobacillus sp. JPLAk1, Paenibacillus pabuli, Paenibacillus xylanilyticus strain XIL14, Virgibacillus necropolis; eight Microbacterium groups - Acinetobacter sp. ANT9054, Arthrobacter sp. AK-1, Arthrobacter sp. Sphe3, [Brevibacterium] frigoritolerans, Rumen bacterium R4-4, three uncultured bacterium groups uncultured bacterium clone Y2, Uncultured soil bacterium clone TA12, and three Enterococci - Enterococcus avium, and Enterococcus faecium strain R0026, Enterococcus pseudoavium (Table 2).

A phylogenetic tree was also constructed for the anaerobic cultures using data generated through the BLAST search (Fig. 7). The anaerobic data showed a wider microbial diversity 
Table 3 - Comparison of $\mathbf{C r}(\mathrm{VI})$ reduction between the indigenous culture and cultures isolated earlier

\begin{tabular}{|c|c|c|c|c|c|}
\hline \multirow[t]{2}{*}{ Culture type } & \multirow{2}{*}{$\begin{array}{c}\text { Initial Cr(VI) } \\
\text { concentration, } \\
\text { mg/L }\end{array}$} & \multicolumn{2}{|c|}{ Culture Conditions } & \multirow{2}{*}{$\begin{array}{l}\% \text { Removal } \\
\text { at } 24 \mathrm{~h}\end{array}$} & \multirow{2}{*}{$\begin{array}{l}\% \text { Removal } \\
\text { at } 48 \mathrm{~h}\end{array}$} \\
\hline & & Temperature, ${ }^{\circ} \mathrm{C}, \mathrm{O}_{2}$ requirement & $\begin{array}{c}\text { Viable cell concentration, } \\
\text { cells } / \mathrm{mL}\end{array}$ & & \\
\hline Brits culture $^{a}$ & 100 & $30 \pm 1.0$, Aerobic & $5.20 \times 10^{9}$ & 97.9 & 100.0 \\
\hline Brits culture $^{\mathrm{b}}$ & 99 & $30 \pm 1.0$, Anaerobic & $1.58 \times 10^{9}$ & 67.1 & 89.9 \\
\hline $\begin{array}{l}\text { Pseudomonas } \\
\text { fluorescens LB300 }\end{array}$ & 90 & $30 \pm 0.5$, Aerobic & $1.00 \times 10^{10}$ & 22.2 & 31.1 \\
\hline Bacillus sp. ${ }^{\mathrm{d}}$ & 94 & $30 \pm 0.5$, Aerobic & $9.80 \times 10^{9}$ & 7.5 & 20.2 \\
\hline $\begin{array}{l}\text { Escherichia coli ATCC } \\
33456^{\mathrm{e}}\end{array}$ & 120 & $30 \pm 0.5$, Anaerobic/micro-aerobic & $9.00 \times 10^{9}$ & 7.5 & 16.7 \\
\hline $\begin{array}{l}\text { a This study, grown } \\
\text { b This study, grown } \\
\text { c Chirwa and Wang, } \\
\text { d Chirwa and Wang } \\
\text { e Wang and Shen, } 1\end{array}$ & $\begin{array}{l}\text { erobically. } \\
\text { naerobically. } \\
\text { 997b. } \\
997 a . \\
7 .\end{array}$ & & & & \\
\hline
\end{tabular}

probably due to the partially anaerobic conditions in the aeration tanks at the Wastewater Treatment Plant from which the bacteria was originally collected.

\subsection{Performance evaluation}

\subsubsection{Comparison with previous isolates}

The dried sludge cultures from the Wastewater Treatment Works at Brits (NW) reduced $\mathrm{Cr}(\mathrm{VI})$ at higher concentrations and at a higher rate than known $\mathrm{Cr}(\mathrm{VI})$ reducing cultures including the pure cultures of Bacillus sp. [isolated from a $\mathrm{Cr}$ (VI) contaminated site in Newark (New Jersey) (Chirwa and Wang, 1997a)], Pseudomonas fluorescens LB300 [originally isolated from soil (Chirwa and Wang, 1997b)], and Escherichia coli ATCC 33456 [purchased (Wang and Shen, 1997)]. Comparison of $\mathrm{Cr}(\mathrm{VI})$ removal at $48 \mathrm{~h}$ incubation for $90-120 \mathrm{mg} \mathrm{Cr}(\mathrm{VI}) / \mathrm{L}$ cultures shows $\mathrm{Cr}(\mathrm{VI})$ removal rate in indigenous sludge culture approximately 3, 8, and 8 times higher than values observed in P. fluorescens LB300 (Chirwa and Wang, 1997b; Bopp and Ehrlich, 1988), Bacillus sp. (Chirwa and Wang, 1997a)

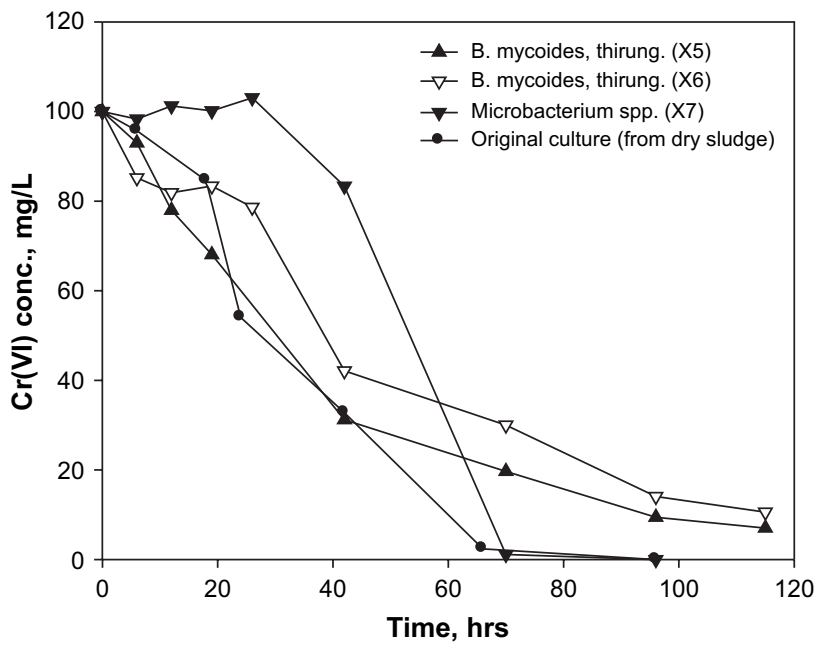

Fig. 8 - $\mathrm{Cr}(\mathrm{VI})$ reduction in individual isolates under aerobic conditions (resting cells: $3.3 \pm 3.1 \times 10^{8} \mathrm{CFU} / \mathrm{mL}$ ). and E. coli ATCC 33456 (Wang and Shen, 1997), respectively (Table 3).

\subsubsection{Purified cultures versus consortium}

$\mathrm{Cr}$ (VI) reduction in pure cultures (X1-X7) was compared with the $\mathrm{Cr}(\mathrm{VI})$ reduction in the original consortium culture from the dried sludge. An example of the comparative data analysis is shown in Fig. 8 with the B. mycoides/thuringiensis (X5 and X6) culture and the Microbacterium sp. The preliminary analysis showed that the performance of different species matched that of the consortium culture at different times during incubation. For example, $\mathrm{Cr}(\mathrm{VI})$ reduction rate in the culture $\mathrm{X} 5$ was approximately equivalent to that of the consortium culture during the first $40 \mathrm{~h}$ of incubation after which, the removal rate was significantly slower. On the other hand, the

Table 4 - Comparison $\mathrm{Cr}(\mathrm{VI})$ reduction between the indigenous natural consortium culture, its isolated species and cultures isolated earlier

\begin{tabular}{|c|c|c|}
\hline Culture type & $\begin{array}{c}\text { Initial } \mathrm{Cr}(\mathrm{VI}) \\
\text { concentration, } \\
\mathrm{mg} / \mathrm{L}\end{array}$ & $\begin{array}{l}\text { \% Removal } \\
\text { after } 24 \mathrm{~h}\end{array}$ \\
\hline Natural Brit's consortium ${ }^{a}$ & 100 & 100 \\
\hline $\mathrm{X} 1$ & 100 & 56.8 \\
\hline $\mathrm{X} 2$ & 100 & 61.9 \\
\hline $\mathrm{X} 3$ & 100 & 59.7 \\
\hline $\mathrm{X} 4$ & 100 & 64.4 \\
\hline $\mathrm{X} 5$ & 100 & 69.98 \\
\hline $\mathrm{x} 6$ & 100 & 67.7 \\
\hline $\mathrm{X} 7$ & 100 & 38.1 \\
\hline $\mathrm{X} 1+\mathrm{X} 2+\mathrm{X} 3+\mathrm{X} 4^{\mathrm{b}}$ & 100 & 91.8 \\
\hline $\mathrm{X} 5+\mathrm{X} 6^{\mathrm{b}}$ & 100 & 84.6 \\
\hline $\begin{array}{l}\mathrm{X} 1+\mathrm{X} 2+\mathrm{X} 3+\mathrm{X} 4+\mathrm{X} 5+\mathrm{X} 6+\mathrm{X}^{\mathrm{b}} \\
\quad \text { (All seven species) }\end{array}$ & 100 & 94.3 \\
\hline Pseudomonas fluorescens LB300 ${ }^{C}$ & 90 & 22.2 \\
\hline Bacillus sp. ${ }^{c}$ & 94 & 7.5 \\
\hline Escherichia coli ATCC $33456^{\mathrm{d}}$ & 120 & 7.5 \\
\hline $\begin{array}{l}\text { a Natural consortium from Brits. } \\
\text { b Recombination of isolates. } \\
\text { c Chirwa and Wang, 1997a,b. } \\
\text { d Wang and Shen, } 1997 .\end{array}$ & & \\
\hline
\end{tabular}


$\mathrm{Cr}(\mathrm{VI})$ removal in the Microbacterium culture (X7) was equivalent to the consortium culture removal after $75 \mathrm{~h}$ incubation. This shows that a fast performing culture may be more susceptible to $\mathrm{Cr}$ (VI) toxicity. Such a culture may act earlier in the presence of other more resilient slower performing cultures. This further indicates the importance of synergism for optimal performance of the culture as the main reason why individual cultures could not perform as well as the original mixed-culture consortium.

\subsubsection{Performance validation - reconstituted consortium}

Further analysis was conducted using individual isolates to determine the $\mathrm{Cr}(\mathrm{VI})$ reduction rate in purified cultures. The data in Table 4 confirm that no species acting alone achieved the same level of $\mathrm{Cr}(\mathrm{VI})$ reduction rate as the original consortium. Additionally, reconstituted cultures, e.g., $\mathrm{X} 1+\mathrm{X} 2+\mathrm{X} 3+\mathrm{X} 4$, performed better than individual cultures. For example, $\mathrm{X} 5$ and $\mathrm{X} 6$ acting alone achieved 70.0 and $67.7 \% \mathrm{Cr}(\mathrm{VI})$ removal in $24 \mathrm{~h}$, but when grown together as a mixed-culture, they achieved $84.6 \%$ with the same time of incubation $(24 \mathrm{~h})$.

In the same table (Table 4), the fully reconstituted consortium from individual pure cultures $(\mathrm{X} 1+\mathrm{X} 2+\mathrm{X} 3+$ $\mathrm{X} 4+\mathrm{X} 5+\mathrm{X} 6+\mathrm{X} 7$ ) showed $94.3 \% \mathrm{Cr}(\mathrm{VI})$ removal after $24 \mathrm{~h}$ and complete removal after $28.5 \mathrm{~h}$ (not shown). This indicates that some synergistic process occurred that resulted in higher performance of the mixed-culture. This also validates the capability of the CRB from the dried sludge.

One experiment conducted at an initial $\mathrm{Cr}(\mathrm{VI})$ concentration of $100 \mathrm{mg} / \mathrm{L}$ showed that addition of pure cultures X5 and X6 to the mixed-culture containing X1, X2, X3, and X4 improved the culture performance by $7.2 \%$ (i.e., $84.2-91.8 \%$ ) after incubation for $22.5 \mathrm{~h}$. These experiments led us to the assumption that synergistic processes occurred between species that resulted in the higher performance of combined cultures.

\section{Conclusion}

The culture isolated from dried activated sludge from aeration tanks at the Water Treatment Works in Brits reduced $\mathrm{Cr}(\mathrm{VI})$ at higher concentrations and shorter incubation times than known cultures studied previously in 1994 and 1997. Characterisation using 16S rRNA fingerprinting yielded seven identifiable potential $\mathrm{Cr}(\mathrm{VI})$ reducing species in aerobic cultures. The independent species in the aerobic cultures were predominantly Gram-positive Bacilli. The individual colonies from anaerobic cultures were predominantly Gram-negative. Further characterisation under anaerobic conditions showed a more diverse culture with 18 species identified. The original consortium and a consortium reconstituted from individual isolates performed better than any of the species acting alone, suggesting possible existence of interspecies interactions necessary for optimum $\mathrm{Cr}(\mathrm{VI})$ removal in the original culture.

\section{Acknowledgements}

The research was funded by the National Research Foundation (NRF) of South Africa through the NRF Focus Areas Grant
No. FA2006031900007 awarded to Prof Evans M.N. Chirwa of the University of Pretoria.

\section{R E F E R E N C E S}

Ackerley, D.F., Gonzalez, C.F., Keyhan, M., Blake, R., Matin, A., 2004. Mechanism of chromate reduction by the Escherichia coli protein, NfsA, and the role of different chromate reductases in minimizing oxidative stress during chromate reduction. Environmental Microbiology 6 (8), 851-860.

APHA, 2005. Standard methods for the examination of water and wastewater. In: Eaton, A.D., Clesceri, L.S., Rice, E.W., Greenberg, A.E., Franson, M.A.H. (Eds.), 21st ed. American Public Health Association, American Water Works Association, Water Environment Federation, USA (centennial edition).

Baldi, F., Vaughan, A.M., Olson, G.J., 1990. Chromium(VI)-resistant yeast isolated from a sewage treatment plant receiving tannery wastes. Applied and Environmental Microbiology 56 (4), 913-918.

Bopp, L.H., Ehrlich, H.L., 1988. Chromate resistance and reduction in Pseudomonas fluorescens strain LB300. Archives of Microbiology 150, 426-431.

Brock, T.D., Madigan, M.T., 1991. Biology of Microorganisms, sixth ed. Prentice Hall, NJ.

Chang, I.S., Kim, B.H., 2007. Effect of sulfate reduction activity on biological treatment of hexavalent chromium [Cr(VI)] contaminated electroplating wastewater under sulfate-rich condition. Chemosphere 68 (2), 218-226.

Chen, Y., Gu, G., 2005. Preliminary studies on continuous chromium(VI) biological removal from wastewater by anaerobic-aerobic activated sludge process. Bioresource Technology 96 (15), 1713-1721.

Chirwa, E.M.N., Wang, Y.T., 2000. Simultaneous Cr(VI) reduction and phenol degradation in an anaerobic consortium of bacteria. Water Research 34 (8), 2376-2384.

Chirwa, E.M.N., Wang, Y.T., 1997a. Hexavalent chromium reduction by Bacillus sp. in a packed-bed bioreactor. Environmental Science and Technology 31 (5), 1446-1451.

Chirwa, E.M.N., Wang, Y.T., 1997b. Chromium(VI) reduction by Pseudomonas fluorescens LB300 in fixed-film bioreactor. Journal of Environmental Engineering 123 (8), 760-766.

Chuan, M., Liu, J., 1996. Release behavior of chromium from tannery sludge. Water Research 30 (4), 932-938.

Coenye, T., Falsen, E., Vancanneyt, M., Hoste, B., Govan, J.R.W., Kersters, K., Vandamme, P., 1999. Classification of Alcaligenes faecalis-like isolates from the environment and human clinical samples as Ralstonia gilardii sp. nov. International Journal of Systematic Bacteriology 49, 405-413.

Dermou, E., Velissariou, A., Xenos, D., Vayenas, D.V., 2005. Biological chromium(VI) reduction using a trickling filter. Journal of Hazardous Materials 126 (1-3), 78-85.

Federal Register, 2004. Occupational safety and health administration. Occupational exposure to hexavalent chromium. Federal Register 69, 59404.

Ganguli, A., Tripathi, A.K., 2002. Bioremediation of toxic chromium from electroplating effluent by chromate-reducing Pseudomonas aeruginosa A2 Chr in two bioreactors. Applied Microbiology and Biotechnology 58, 416-420.

Ginestet, P., Audic, J.M., Urbain, V., Block, J.C., 1998. Estimation of nitrifying bacterial activities by measuring oxygen uptake in the presence of the metabolic inhibitors allylthiourea and azide. Applied and Environmental Microbiology 64 (6), 2266-2268.

Horitsu, H., Futo, S., Miyazawa, Y., Ogai, S., Kawai, K., 1987. Enzymatic reduction of hexavalent chromium by hexavalent 
tolerant Pseudomonas ambigua G-1. Agricultural and Biological Chemistry 51 (9), 2417-2420.

Ishibashi, Y., Cervantes, C., Silver, S., 1990. Chromium reduction in Pseudomonas putida. Applied and Environmental Microbiology 56 (7), 2268-2270.

Kiilunen, M., 1994. Occupational exposure to chromium and nickel in Finland - analysis of registries of hygienic measurements and biological monitoring. Annals of Occupational Hygiene 38 (2), 171-187.

Lawson, E.N., 1997. The biological removal of hexavalent chrome from ferrochrome manufacturing process waters. In: Proceedings of International Biohydrometallurgy Symposium 1997, Sydney, Australia, p. 302.

Levitskaia, T.G., O'Hara, M.J., Sinkov, S.I., Egorov, O.B., 2008. Direct spectrophotometric analysis of $\mathrm{Cr}$ (VI) using a Liquid Waveguide Capillary Cell. Applied Spectroscopy 62 (1), 107-115.

Lovley, D.R., Phillips, E.J.P., 1994. Reduction of chromate by Desulfovibrio vulgaris and its $c_{3}$ cytochrome. Applied and Environmental Microbiology 60 (2), 726-728.

Mintek, 2004. Mining and Metallurgy in South Africa, a Pictorial History. Mintek, in association with Phase 4, p. 50.

Nkhalambayausi-Chirwa, E.M., Wang, Y.T., 2005. Modeling Cr(VI) reduction and phenol degradation in a coculture biofilm reactor. Journal of Environmental Engineering 131 (11), 1495-1506.

Ohtake, H., Fujii, E., Toda, K., 1990. Reduction of toxic Cr(VI) in an industrial effluent by use of a $\mathrm{Cr}(\mathrm{VI})$-reducing strain Enterobacter cloacae HO1. Environmental Technology Letters 11, 663-668.

Palmer, C.D., Wittbrodt, P.R., 1991. Processes affecting the remediation of chromium-contaminated sites. Environmental Health Perspectives 92, 25-40.

Patterson, J.W., 1985. Industrial Wastewater Treatment Technology. Butterworth Publishers, Stoneham, MA, pp. 53-393.

Ramírez-Ramírez, R., Calvo-Méndez, C., Ávila-Rodríguez, M., Lappe, P., Ulloa, M., Vázquez-Juárez, R., Gutiérrez-Corona, J.F., 2004. $\mathrm{Cr}$ (VI) reduction in a chromate-resistant strain of
Candida maltosa isolated from the leather industry. Antonie van Leeuwenhoek 85 (1), 63-68.

Romanenko, V.I., Koren'kov, V.N., 1977. A pure culture of bacteria utilizing chromate and dichromate as hydrogen acceptors in growth under anaerobic conditions. Mikrobiologiya 46, 414-417.

Shen, H., Wang, Y.T., 1993. Characterization of enzymatic reduction of hexavalent chromium by Escherichia coli ATCC 33456. Applied and Environmental Microbiology 59 (11), 3771-3777.

Shen, H., Wang, Y.T., 1994a. Biological reduction of chromium by E. coli. Journal of Environmental Engineering 120, 560-572.

Shen, H., Wang, Y.T., 1994b. Modeling hexavalent chromium reduction in E. coli 33456. Biotechnology and Bioengineering 43, 293-300.

Stasinakis, A.S., Thomaidis, N.S., Mammais, D., Lekkas, T.D., 2004. Investigation of $\mathrm{Cr}(\mathrm{VI})$ reduction in continuous-flow activated sludge systems. Chemosphere 57 (9), 1069-1077.

Suzuki, T., Miyata, N., Horitsu, H., Kawai, K., Takamizawa, K., Tai, Y., Okazaki, M., 1992. NAD(P)H-dependent chromium (VI) reductase of Pseudomonas ambigua G-1: a $\mathrm{Cr}(\mathrm{V})$ intermediate is formed during the reduction of $\mathrm{Cr}$ (VI) to $\mathrm{Cr}(\mathrm{III})$. Journal of Bacteriology 174 (16), 5340-5345.

U.S.EPA, 1978. Reviews of the Environmental Effects of Pollutants - III. Chromium. EPA 600/1-78-023. District of Columbia, Washington.

U.S.EPA, 2001. Chromite ore from the Transvaal Region of South Africa; toxic chemical release reporting; community right-toknow, 40 CFR Part 372.

Viamajala, S., Smith, W.A., Sani, R.K., Apel, W.A., Petersen, J.A., Neal, A.L., Roberto, F.F., Newby, D.T., Peyton, B.M., 2006. Isolation and characterization of $\mathrm{Cr}(\mathrm{VI})$ reducing Cellulomonas spp. from subsurface soils: implications for long-term chromate reduction. Bioresource Technology 98 (3), 612-622.

Wang, Y.T., Shen, H., 1997. Modelling Cr(VI) reduction by pure bacterial cultures. Water Research 31 (3), 727-732.

Zakaria, Z.A., Zakaria, Z., Surif, S., Ahmad, W.A., 2007. Biological detoxification of $\mathrm{Cr}(\mathrm{VI})$ using wood-husk immobilized Acinetobacter haemolyticus. Journal of Hazardous Materials 148 (1-2), 164-171. 